\title{
PANDANGAN GURU TERHADAP PELAKSANAAN KURIKULUM 2013 DALAM PEMBELAJARAN FISIKA SMK DI KOTA SURABAYA
}

\author{
${ }^{1)}$ Rudy Kustijono, ${ }^{2)}$ Elok Wiwin HM. \\ 1) Jurusan Fisika FMIPA Universitas Negeri Surabaya \\ ${ }^{2)}$ SMK Negeri 12 Surabaya \\ e-mail: rudyunesa@gmail.com
}

\begin{abstract}
Abstrak
Telah dilakukan penelitian tentang pandangan guru terhadap pelaksanaan Kurikulum 2013 dalam pembelajaran Fisika SMK di kota Surabaya Tujuan penelitian adalah untuk menjaring pandangan guru terkait tingkat kesiapan dan kelayakan pelaksanaan Kurikulum 2013 untuk pembelajaran Fisika SMK di kota Surabaya meliputi: pemahaman prinsip penilaian, penyusunan RPP, kegiatan pembelajaran, kegiatan penilaian, harapan dan tantangan pelaksanaan Kurikulum 2013. Jenis penelitian adalah survei dengan objek penelitian guru Fisika SMK di kota Surabahya. Hasil penelitian menyimpulkan: 1) Para guru berpandangan belum sepenuhnya memahami prinsip pembelajaran terutama yang terkait dengan: perbedaan pendekatan tekstual dengan pendekatan ilmiah, perbedaan pembelajaran parsial dengan pembelaran terpadu, perbedaan pembelajaran yang menekankan jawaban tunggal dengan pembelajaran yang membutuhkan jawaban multi dimensi, perbedaan pembelajaran verbalisme dengan pembelajaran yang aplikatif, dan pembelajaran yang berprinsip bahwa siapa saja adalah guru, siapa saja adalah siswa, dan di mana saja adalah kelas; 2) Para guru berpandangan belum sepenuhnya memahami prinsip penilaian diantaranya: cara menilai kompetensi sikap, cara menilai keterampilan, dan menyusun instrumen penilaian yang sesuai kaidah; 3) Para guru berpandangan penyusunan RPP masih terkendala terutama pada: berbagai sumber belajar (buku teks, internet, lingkungan alam dan sosial), media pembelajaran yang bervariasi, media yang sesuai dengan materi pembelajaran, pendekatan pembelajaran saintifik. penilaian autentik, penilaian yang sesuai dengan indikator pencapaian kompetensi, dan pedoman penskoran; 4) Para guru berpandangan masih belum dapat melaksanakan kegiatan pembelajaran yang sesuai dengan standar proses meliputi: belum terbiasa menyampaikan kompetensi yang akan dicapai kepada peserta didik, belum melaksanakan pembelajaran kontekstual dan saintifik, belum memfasilitasi peserta didik mengolah/ menganalisis informasi untuk membuat kesimpulan, belum menggunakan media pembelajaran yang bervariasi, dan media yang digunakan belum menghasilkan pesan yang menarik; 5) Para guru berpandangan masih belum dapat melaksanakan penilaian sesuai standar penilaian terutama: bagaimana cara mengembangkan instrumen penilaian yang sesuai dengan kaidah, dan bagaimana cara mengembangkan rubrik penilaian dari instrumen yang dikembangkan tersebut; 6) Harapan dari pelaksanaan Kurikulum 2013 adalah kurikulum tersebut dapat dilaksanakan sesuai dengan standar yang telah ditetapkan, sedangkan tantangan terbesar dari pelaksanaan Kurikulum 2013 adalah bagaimana para guru dapat menyikapi dan mengupayakan pelaksanaan secara tepat kurikulum tersebut.
\end{abstract}

Kata Kunci: Kurikulum 2013, pendekatan saintifik, keterampilan berpikir, kreativitas, 


\section{PENDAHULUAN}

Kurikulum 2013 merupakan pengembangan dan penyempurnaan dari kurikulum sebelumnya untuk merespon berbagai tantangan internal maupun eksternal. Salah satu alasan pentingnya Kurikulum 2013 adalah bahwa generasi muda Indonesia perlu disiapkan dalam kompetensi sikap, keterampilan, dan pengetahuan. Digunakannya pendekatan saintifik dalam Kurikulum 2013 adalah satu upaya untuk memenuhi kebutuhan tersebut. Pelaksanaan Kurikulum 2013 dipandang sebagai kebutuhan yang mendesak. Oleh karenanya kurikulum tersebut sudah dilaksanakan secara terbatas mulai tahun pelajaran 2013-2014 pada sekolah-sekolah yang memenuhi persyaratan dan ditetapkan secara selektif. Tetapi pada tahun pelajaran 2014-2015 Kurikulum 2013 tersebut direncanakan dilaksanakan pada semua sekolah. Menurut Mendikbud (dikutip Marsigit, 2013) ${ }^{[1]}$, jika pelaksanaan Kurikulum 2013 ditunda maka taruhannya adalah masa depan generasi bangsa.

Sebagian besar kalangan termasuk para pakar memandang pendekatan saintifik sebagai discovery method atau metode penemuan. Pendekatan saintifik tersebut sebenarnya sesuai dengan pengembangan kompetensi yang diperlukan untuk menghadapi abad 21. Menurut Trilling dan Hood (1999) ${ }^{[2]}$, para peramal masa depan (futurist) mengatakan bahwa abad 21 sebagai abad pengetahuan, karena pengetahuan akan menjadi landasan utama segala aspek kehidupan. Ruiz dan Primo $(2009)^{[3]}$ menyatakan bahwa pada tahun 2007 The National Academies menyelenggarakan lokakarya hasil penelitian yang terkait dengan keterampilan masa depan. Hasil lokakarya tersebut menyimpulkan bahwa setidaknya diperlukan lima keterampilan yang secara luas diperlukan di berbagai pekerjaan, yaitu: adaptability, complex communications/social skills, nonroutine problem solving, self-management /self-development, dan systems thinking. De Vito (1989) ${ }^{[4]}$ menyatakan bahwa untuk mengantisipasi abad 21, model pembelajaran yang diperlukan adalah yang memungkinkan terbudayakannya kecakapan berpikir ilmiah, terkembangkannya "sense of inquiry" dan kemampuan berpikir kreatif siswa.

Wyatt (eduscapes.com) ${ }^{[5]}$ membahas taksonomi Benjamin Bloom (1956) yang telah mengembangkan tingkatan klasifikasi intelektual dalam belajar. Taksonomi tersebut mengandung tiga ranah yang saling tumpangsuh yaitu kogntif, psikomotor, dan afektif. Dalam ranah kognitif, ia mengidentifikasi enam tingkatan: yang meliputi: pengetahuan, pemahaman, penerapan, analisis, sintesis, dan evaluasi. Ranahranah tersebut sampai saat ini masih kita gunakan dalam mengembangkan keterampilan berpikir kritis. Berpikir kritis melibatkan berpikir dan bernalar logis yang mencakup keterampilan seperti membandingkan, mengklasifikasi, mengurutkan, mengidentifikasi sebab akibat, mempolakan, membuat jaringan (webbing), analogi, penalaran deduktif dan induktif, meramal, merencanakan, membuat hipotesis, dan mengkritik.

Yang tidak kalah pentingnya dalam proses pembelajaran adalah mengembangkan kemampuan berfikir kreatif siswa. Berpikir kritis banyak dipikirkan di otak kiri, sedang berpikir kreatif lebih banyak di otak sebelah kanan. Keduanya melibatkan aktivitas "berpikir" yang biasanya kita sebut sebagai HOTS (higher-order thinking skills) yang terkonsentrasi pada tiga kompetensi kognitif tertinggi dari taksonomi Bloom, yaitu analisis, sintesis, dan evaluasi yang perlu dikuasai siswa di kelas. Gie $(2003)^{[6\}}$ memberikan batasan, bahwa berpikir kreatif adalah suatu rangkaian tindakan yang dilakukan orang dengan menggunakan akal budinya untuk menciptakan buah pikiran baru dari kumpulan ingatan yang berisi berbagai ide, keterangan, konsep, pengalaman, dan pengetahuan. Pengertian ini menunjukkan bahwa berpikir kreatif ditandai dengan penciptaan sesuatu yang baru dari hasil berbagai ide, keterangan, konsep, pengalaman, maupun pengetahuan yang ada dalam pikirannya. Berpikir kreatif melibatkan menciptakan sesuatu yang baru 
atau asli. Berpikir kreatif melibatkan keterampilan fleksibilitas, keaslian, kelancaran, elaborasi, curah pendapat (brainstorming), modifikasi, perumpamaan (imagery), berpikir asosiatif, mendaftar atribut, berpikir berkenaan dengan metafora, membuat hubungan.

Tujuan dari berpikir kreatif adalah untuk merangsang keingintahuan dan meningkatkan kemampuan berpikir divergen. Berpikir kreatif adalah suatu aktivitas mental untuk membuat hubungan-hubunan yang terus-menerus, sehingga ditemukan kombinasi yang "benar" atau sampai seseorang itu menyerah. Asosiasi kreatif terjadi melalui kemiripan-kemiripan sesuatu atau melalui pemikiran analogis. Asosiasi ide-ide membentuk ide-ide baru, jadi, berpikir kreatif mengabaikan hubungan-hubungan yang sudah mapan dan menciptakan hubungan-hubungan tersendiri. Pengertian ini menunjukkan bahwa berpikir kreatif merupakan kegiatan mental untuk menemukan suatu kombinasi yang belum dikenal sebelumnya. Berpikir kreatif dapat juga dipandang sebagai suatu proses yang digunakan ketika seorang individu mendatangkan atau memunculkan suatu ide baru. Ide baru tersebut merupakan gabungan-ide-ide sebelumnya yang belum pernah diwujudkan.

Berpikir dengan kritis dan kreatif memungkinkan siswa mempelajari masalah secara sistematik, mempertemukan banyak sekali tantangan dalam suatu cara yang terorganisasi, merumuskan pertanyaanpertanyaan yang inovatif dan merancang penyelesaian yang asli. Kreativitas dan inovasi tersebut menjadi bagian penting dari Kurikulum 2013 karena tema dari kurikulum 2013 adalah (Kemdikbud, 2012) ${ }^{[7]}$ : "Kurikulum yang dapat menghasilkan insan Indonesia yang produktif, kreatif, inovatif, efektif melalui penguatan sikap, keterampilan, dan pengetahuan yang terintegrasi. Untuk menghasilkan insan yang kreatif tersebut dalam proses pembelajaran, Kurikulum 2013 mendukung pendapat Dyers, J.H. et al (2011), Innovators DNA,
Harvard Bus. Review, bahwa kreativitas dapat diperoleh melalui kegiatan (Kemdikbud, 2012) ${ }^{\{7\}}$ :

1. Observing (mengamati)

2. Questioning (menanya)

3. Associating (menalar)

4. Experimenting (mencoba)

5. Networking (membentuk jejaring)

Oleh karena itu, pembelajaran harus mengedepankan pengalaman personal melalui proses mengamati, menanya, menalar, dan mencoba (observation based learning) untuk meningkatkan kreativitas peserta didik. Disamping itu, dibiasakan bagi peserta didik untuk bekerja dalam jejaringan melalui collaborative learning.

Untuk menghasilkan insan yang kreatif tersebut, sistem penilaian pembelajaran dalam Kurikulum 2013 mendukung pendapat Sharp, C., (2004), Developing young children's creativity, what can we learn from research?, yaitu Guru dapat membuat peserta didik berani berperilaku kreatif melalui (Kemdikbud, 2012) ${ }^{[7]}$ :

1. Tugas yang tidak hanya memiliki satu jawaban tertentu yang benar (banyak/semua jawaban benar),

2. Mentolerir jawaban yang nyeleneh,

3. Menekankan pada proses bukan hanya hasil saja, memberanikan peserta didik untuk mencoba, untuk menentukan sendiri yang kurang jelas/lengkap informasinya, untuk memiliki interpretasi sendiri terkait dengan pengetahuan atau kejadian yang diamatinya

4. Memberikan keseimbangan antara yang terstruktur dan yang spontan/ekspresif

Oleh karena itu, Kurikulum 2013 menggunakan standar penilaian yang mencakup pertanyaan yang tidak memiliki jawaban tunggal, memberi nilai bagi jawaban nyeleneh, menilai proses pengerjaannya bukan hanya hasilnya, penilaian spontanitas/ekspresif, dll.

Pengembangan Kurikulum 2013 ditekankan pada penyempurnaan pola pikir, penguatan tata kelola kurikulum, pendalaman dan perluasan materi, penguatan proses pembelajaran, dan penyesuaian beban 


\section{ISSN: 2087-9946}

belajar agar dapat menjamin kesesuaian antara apa yang diinginkan dengan apa yang dihasilkan. Pengembangan kurikulum penting dilaksanakan sejalan dengan kemajuan ilmu pengetahuan, teknologi, dan seni budaya serta perubahan masyarakat pada tataran lokal, nasional, regional, dan global. Berbagai kemajuan dan perubahan itu melahirkan tantangan internal dan eksternal di bidang pendidikan pendidikan. Oleh karena itu, pelaksanaan Kurikulum 2013 merupakan langkah strategis dalam menghadapi globalisasi dan tuntutan masyarakat Indonesia di masa depan.

Menurut Menteri Pendidikan dan Kebudayaan (Kemdikbud, 2013) ${ }^{[8]}$, Pengembangan Kurikulum 2013 dilaksanakan atas dasar beberapa prinsip utama. Pertama, standar kompetensi lulusan diturunkan dari kebutuhan. Kedua, standar isi diturunkan dari standar kompetensi lulusan melalui kompetensi inti yang bebas mata pelajaran. Ketiga, semua mata pelajaran harus berkontribusi terhadap pembentukan sikap, keteram-pilan, dan pengetahuan peserta didik. Keempat, mata pelajaran diturunkan dari kompetensi yang ingin dicapai. Kelima, semua mata pelajaran diikat oleh kompetensi inti. Keenam, keselarasan tuntutan kompetensi lulusan, isi, proses pembelajaran, dan penilaian. Penerapan prinsip-prinsip ini menjadi sangat penting dalam mewujudkan keberhasilan pelaksanaan Kurikulum 2013. Secara teoretik keberhasilan suatu kurikulum secara utuh memerlukan proses panjang, mulai dari kajian dan kristalisasi berbagai gagasan dan konsep ideal tentang pendidikan, pengembangan desain kurikulum, penyiapan dan penugasan pendidik dan tenaga kependidikan, penyediaan sarana dan prasarana, penyiapan tata kelola pelaksanaan kurikulum, pembelajaran, dan penilaian.

Untuk mengawal pelaksanaan Kurikulum 2013 terkait SMK/MAK, pemerintah telah menerbitkan berbagai peraturan diantaranya adalah: 1) Peraturan Pemerintah (PP) No 32 Tahun 2013 tentang Perubahan PP No 19 Tahun 2005 terkait SNP; 2)
Permendikbud No. 54 Tahun 2013 tentang SKL; 3) Permendikbud No. 64 Tahun 2013 tentang Standar Isi; 4) Permendikbud No. 65 Tahun 2013 tentang Standar Proses; 5) Permen-dikbud No. 66 Tahun 2013 tentang Standar Penilaian; 6) Permendikbud No. 70 Tahun 2013 tentang Kerangka Dasar dan Struktur Kurikulum SMK/MAK. Peraturanperaturan tersebut harus mendapatkan perhatian dari pihak-pihak terkait terutama para guru dalam melaksanakan Kurikulum 2013.

Saat ini pengembangan Kurikulum 2013, sudah memasuki tahap pelaksanaan bertahap dan terbatas. Untuk jenjang SMK, pelaksanaan dilaksanakan pada kelas $\mathrm{X}$ pada sebagian kecil SMK/MAK di seluruh wilayah Indonesia. Pentahapan pelaksanaan ini, dimaksudkan untuk memperoleh informasi tingkat keterlaksanaan kurikulum dan memberi peluang bagi penyempurnaan kurikulum secara bertahap. Langkah awal yang telah dilakukan dalam rangka persiapan pelaksanaan Kurikulum 2013 adalah melakukan Pendidikan dan Pelatihan dalam rangka Pelaksanaan Kurikulum 2013 kepada seluruh unsur pendidikan, dalam hal ini pendidik dan tenaga kependidikan di sekolah serta unsur-unsur lain yang terlibat langsung dalam proses pendidikan. Salah satu strategi untuk memahami dan memantapkan pelaksanaan Kurikulum 2013, yaitu melalui Pendidikan dan Pelatihan (Diklat) Pelaksanaan Kurikulum 2013 yang diperuntukkan bagi guru, Kepala Sekolah dan Pengawas Sekolah.

Setelah pelaksanaan Kurikulum 2013 berjalan selama satu semester (gasal tahun pelajaran 2013-2014) oleh sekolah-sekolah sasaran, diperlukan pemantauan untuk mengetahui kesiapan dan kelayakan pelaksanaan Kurikulum 2013 oleh pihakpihak terkait (Guru, Kepala Sekolah, dan Pengawas). Sesuai rencana, Kurikulum 2013 akan dipelaksanaankan pada semua sekolah mulai tahun pelajaran 2014-2015. Tujuan pemantauan adalah untuk mengetahui kendala-kendala yang dihadapi oleh pihakpihak terkait terutama para guru dari sekolah 
ISSN: 2087-9946

yang ada dalam melaksanaankan Kurikulum 2013. Terkait dengan pelaksanaan Kurikulum 2013 tersebut, penulis berkesempatan memberikan sosialisasi pelaksanaan Kurikulum 2013 untuk jenjang SMK yang dilaksanakan oleh Musyawarah Guru Mata Pelajaran Fisika (MGMP Fisika) kota Surabaya sehingga berkesempatan untuk menjaring data-data yang dapat digunakan dalam penelitian ini.

Tujuan penelitian adalah untuk menjaring pandangan guru terkait tingkat kesiapan dan kelayakan pelaksanaan Kurikulum 2013 untuk pembelajaran Fisika SMK di kota Surabaya meliputi:

1. Pandangan guru terhadap pemahaman prinsip pembelajaran

2. Pandangan guru terhadap pemahaman prinsip penilaian

3. Pandangan guru terhadap penyusunan rencana pelaksanaan pembelajaran (RPP)

4. Pandangan guru terhadap kegiatan pembelajaran

5. Pandangan guru terhadap kegiatan penilaian

6. Harapan dan tantangan pelaksanaan Kurikulum 2013

Hasil yang diperoleh dalam penelitian diharapkan dapat menjadi rujukan bagi pihak-pihak terkait (Guru, Kepala Sekolah, dan Pengawas) terutama para guru Fisika SMK dalam mengpelaksanaankan Kurikulum 2013.

\section{METODE PENELITIAN}

Penelitian yang dilakukan merupakan penelitian survei yaitu penelitian yang digunakan untuk mengumpulkan data atau informasi tentang populasi yang besar dengan menggunakan sampel yang relatif kecil (Sukmadinata, 2012) ${ }^{[9]}$. Langkah penelitian survei yang dilakukan dimodifikasi dari Neuman and Lawrence. $(2006)^{[10]}$ adalah sebagai berikut:

1. menentukan teknik penjaringan data, membuat pertanyaan-pertanyaan, dan menentukan kategori responden,.

2. menyiapkan instrumen survei.
3. menentukan sasaran populasi responden yang akan di survei, membuat kerangka sampel survei, dan memilih sampel.

4. menentukan lokasi responden, melakukan wawancara (interview), dan mengumpulkan data dengan angket.

5. Memilah dan mengelompokkan data, mengecek ulang data yang telah diperoleh, dan membuat analisis.

6. menjabarkan hasil penelitian untuk mendapatkan kesimpulan.

Survei dalam penelitian yang dilakukan adalah untuk menjaring pandangan para guru terkait tingkat kesiapan dan kelayakan pelaksanaan Kurikulum 2013 SMK mata pelajaran Fisika di kota Surabaya. Dalam penelitian ini menggunakan responden Guru Fisika SMK di di kota Surabaya (anggota MGMP Fisika SMK kota Surabaya)

Sasaran penelitian adalah pelaksanaan Kurikulum 2013 untuk pembelajaran Fisika SMK. Objek penelitian adalah Guru Fisika SMK di kota Surabaya. Dalam penelitian ini, populasi sasaran adalah seluruh Guru Fisika SMK di kota Surabaya (anggota MGMP Fisika kota Surabaya). Penelitian ini menggunakan total sampling karena seluruh unsur populasi digunakan sebagai sumber data (responden).

Teknik penjaringan dan pengumpulan data yang digunakan dalam penelitian ini meliputi :

1. Teknik angket atau kuesioner (questionnaire) yaitu teknik pengumpulan data secara tidak langsung dengan menggunakan angket yang berupa pertanyaan dan pernyataan yang harus dijawab atau direspon responden. Angket berupa pertanyaan dan pernyataan terkait pelaksanaan Kurikulum 2013 yang meliputi: 1) Pandangan guru terhadap pemahaman prinsip pembelajaran, 2) Pandangan guru terhadap pemahaman prinsip penilaian, 3) Pandangan guru terhadap penyusunan rencana pelaksanaan pembelajaran (RPP), 4) Pandangan guru terhadap kegiatan 
pembelajaran, 5) Pandangan guru terhadap kegiatan penilaian

2. Wawancara (interview) yaitu teknik pengumpulan data dengan melakukan tatap muka dengan responden secara individu maupun kelompok. Wawancara dalam penelitian ini dilakukan untuk melengkapi dan memperbaiki data yang diperoleh dari teknik angket.

Instrumen penelitian adalah alat atau fasilitas yang digunakan oleh peneliti dalam mengumpulkan data agar pekerjaannya lebih mudah dan hasilnya lebih baik, dalam arti lebih cermat, lengkap, dan sistematis, sehingga lebih mudah diolah (Suharsimi, 2002) ${ }^{[11]}$. Instrumen yang digunakan terdiri dari komponen Kurikulum 2013 dan pandangan guru yang berupa pernyataan sudah atau belum dilaksanakan.

Analisis data yang digunakan dalam penelitian ini adalah statistik deskriptif. Data yang bersifat kuantitatif diolah dengan statistik yang sesuai, sedangkan data yang bersifat kualitatif diolah secara deskriptif.

\section{HASIL DAN PEMBAHASAN}

\section{Pandangan Guru Terhadap Pemahaman Prinsip Pembelajaran}

Setelah dilakukan pemilahan dan pengelompokan data dari angket, dapat disajikan pandangan guru terhadap pemahaman prinsip pembelajaran seperti Tabel 1 sebagai berikut:

Tabel 1. Pandangan Guru Terhadap Prinsip Pembelajaran

\begin{tabular}{|c|c|c|c|}
\hline \multirow{2}{*}{ No } & \multirow{2}{*}{ Komponen Kurikulum 2013} & \multicolumn{2}{|c|}{ Pelaksanaan (\%) } \\
\hline & & Sudah & Belum \\
\hline 1 & Memahami perubahan dari peserta didik diberi tahu menuju peserta didik mencari tahu & 90 & 10 \\
\hline 2 & $\begin{array}{l}\text { Memahami perubahan dari guru sebagai satu-satunya sumber belajar menjadi belajar } \\
\text { berbasis aneka sumber belajar }\end{array}$ & 92 & 8 \\
\hline 3 & $\begin{array}{l}\text { Memahami perubahan dari pendekatan tekstual menuju proses sebagai penguatan } \\
\text { penggunaan pendekatan ilmiah }\end{array}$ & 52 & 48 \\
\hline 4 & $\begin{array}{l}\text { Memahami perubahan dari pembelajaran berbasis konten menuju pembelajaran berbasis } \\
\text { kompetensi }\end{array}$ & 76 & 24 \\
\hline 5 & Memahami perubahan dari pembelajaran parsial menuju pembelajaran terpadu & 46 & 54 \\
\hline 6 & $\begin{array}{l}\text { Memahami perubahan dari pembelajaran yang menekankan jawaban tunggal menuju } \\
\text { pembelajaran dengan jawaban yang kebenarannya multi dimensi }\end{array}$ & 30 & 70 \\
\hline 7 & Memahami perubahan dari pembelajaran verbalisme menuju keterampilan aplikatif, & 44 & 56 \\
\hline 8 & $\begin{array}{l}\text { Memahami peningkatan dan keseimbangan antara keterampilan fisikal (hardskills) dan } \\
\text { keterampilan mental (softskills), }\end{array}$ & 60 & 40 \\
\hline 9 & $\begin{array}{l}\text { Memahami pembelajaran yang mengutamakan pembudayaan dan pemberdayaan } \\
\text { peserta didik sebagai pembelajar sepanjang hayat }\end{array}$ & 74 & 26 \\
\hline 10 & $\begin{array}{l}\text { Memahami pembelajaran yang menerapkan nilai-nilai dengan memberi keteladanan (ing } \\
\text { ngarso sung tulodo),membangun kemauan (ing madyo mangun karso), dan } \\
\text { mengembangkan kreativitas peserta didik dalam proses pembelajaran (tut wuri } \\
\text { handayani) }\end{array}$ & 76 & 24 \\
\hline 11 & Memahami pembelajaran yang berlangsung di rumah, di sekolah, dan di masyarakat & 74 & 26 \\
\hline 12 & $\begin{array}{l}\text { Memahami pembelajaran yang menerapkan prinsip bahwa siapa saja adalah guru, siapa } \\
\text { saja adalah siswa, dan di mana saja adalah kelas }\end{array}$ & 44 & 56 \\
\hline 13 & $\begin{array}{l}\text { Memahami pemanfaatan teknologi informasi dan komunikasi untuk meningkatkan } \\
\text { efisiensi dan efektivitas pembelajaran }\end{array}$ & 72 & 28 \\
\hline 14 & $\begin{array}{l}\text { Memahami pengakuan atas perbedaan individual dan latar belakang budaya peserta } \\
\text { didik. }\end{array}$ & 86 & 14 \\
\hline
\end{tabular}

Berdasarkan Tabel 1 dapat diketahui bahwa secara umum para guru belum sepenuhnya memahami prinsip-prinsip pembelajaran yang sesuai dengan Kuri- kulum 2013. Prinsip pembelajaran yang belum dipahami tersebut terutama meliputi: 1) perubahan pendekatan tekstual menuju pendekatan ilmiah, 2) perubahan pembe- 


\section{ISSN: 2087-9946}

lajaran parsial menuju pembelaran terpadu, 3) perubahan pembelajaran yang menekankan jawaban tunggal menuju pembelajaran yang membutuhkan jawaban multi dimensi, 4) perbuahan pembelajaran verbalisme menuju pembelajaran yang aplikatif, dan 5) pembelajaran yang menerapkan prinsip bahwa siapa saja adalah guru, siapa saja adalah siswa, dan di mana saja adalah kelas. Kenyataan tersebut dapat dimaklumi karena selama ini para guru terbiasa menggunakan pembelajaran yang berpusat pada guru (teacher centered) dan guru masih dominan dalam pembelajaran.

\section{Pandangan Guru Terhadap Pemahaman Prinsip Penilaian}

Setelah dilakukan pemilahan dan pengelompokan data dari angket, dapat disajikan pandangan guru terhadap pemahaman prinsip penilaian seperti Tabel 2 sebagai berikut:

Tabel 2. Pandangan Guru Terhadap Prinsip Penilaian

\begin{tabular}{|c|l|c|c|}
\hline \multirow{2}{*}{ No } & \multicolumn{1}{|c|}{ Komponen Kurikulum 2013 } & \multicolumn{1}{|c|}{ Pelaksanaan (\%) } \\
\cline { 2 - 4 } & \multicolumn{1}{|c|}{ Sudah } & Belum \\
\hline 1 & $\begin{array}{l}\text { Memahami penilaian hasil belajar peserta didik mencakup kompetensi sikap, } \\
\text { pengetahuan, dan keterampilan yang dilakukan secara berimbang }\end{array}$ & 84 & 16 \\
\hline 2 & $\begin{array}{l}\text { Memahami pendidik melakukan penilaian kompetensi sikap melalui observasi, penilaian } \\
\text { diri, penilaian "teman sejawat"(peer evaluation) oleh peserta didik dan jurnal }\end{array}$ & 74 & 26 \\
\hline 3 & $\begin{array}{l}\text { Memahami pendidik menilai kompetensi pengetahuan melalui tes tulis, tes lisan, dan } \\
\text { penugasan }\end{array}$ & 92 & 36 \\
\hline 4 & $\begin{array}{l}\text { Memahami pendidik menilai kompetensi keterampilan melalui penilaian kinerja, yaitu } \\
\text { penilaian yang menuntut peserta didik mendemonstrasikan suatu kompetensi tertentu } \\
\text { dengan menggunakan tes praktik, projek, dan penilaian portofolio }\end{array}$ & 64 & 36 \\
\hline
\end{tabular}

Berdasarkan Tabel 2 dapat diketahui bahwa secara umum para guru belum sepenuhnya memahami prinsip-prinsip penilaian yang sesuai dengan Kurikulum 2013. Prinsip penilaian yang belum dipahami tersebut diantaranya: 1) bahwa penilaian kompetensi sikap dapat dilakukan melalui observasi, penilaian diri, penilaian "teman sejawat" (peer evaluation) oleh peserta didik dan jurnal, 2) bahwa menilai kompetensi keterampilan dapat dilakukan melalui penilaian kinerja, yaitu penilaian yang menuntut peserta didik mendemonstrasikan suatu kompetensi tertentu dengan menggunakan tes praktik, projek, dan penilaian portofolio, 3) bahwa instrumen penilaian harus memenuhi persyaratan: substansi, konstruksi, dan penggunaan bahasa yang baik dan benar serta komunikatif. Kenyataan tersebut dapat dimaklumi karena selama ini para guru hanya terbiasa menggunakan penilaian yang banyak menekankan pada aspek pengetahuan saja. Berdasarkan wawancara yang telah dilakukan, selama ini para guru sudah terbiasa dengan menilai kompetensi pengetahuan melalui tes tulis, tes lisan, dan penugasan. Namun demikian penilaian guru masih menekankan pada jawaban tunggal dan belum terbiasa dengan jawaban yang membutuhkan pemikiran multi dimensi.

\section{Pandangan Guru Terhadap Penyusunan RPP}

Setelah dilakukan pemilahan dan pengelompokan data dari angket, dapat disajikan pandangan guru terhadap penyusunan RPP seperti Tabel 3 sebagai berikut: 
Tabel 3. Pandangan Guru Terhadap Penyusunan RPP

\begin{tabular}{|c|l|c|c|}
\hline \multirow{1}{*}{ No Komponen Kurikulum 2013 } & \multicolumn{1}{|c|}{ Pelaksanaan (\%) } \\
\cline { 2 - 4 } & \multicolumn{1}{|c|}{ Sudah } & Belum \\
\hline 1 & $\begin{array}{l}\text { Menulis identitas mapel memuat satuan pendidikan, kelas, semester, mata pelajaran, } \\
\text { materi pokok/ tema, jumlah pertemuan (dan jumlah jam pelajaran) }\end{array}$ & 92 & 8 \\
\hline 2 & Indikator menggunakan kata kerja operasional relevan dengan KD yang dikembangkan. & 90 & 10 \\
\hline 3 & Indikator mencakup komptensi pengetahuan, keterampilan, dan sikap & 92 & 8 \\
\hline 4 & $\begin{array}{l}\text { Tujuan pembelajaran sesuai indikator dan mencakup kompetensi pengetahuan, } \\
\text { keterampilan, dan sikap }\end{array}$ & 92 & 10 \\
\hline 5 & $\begin{array}{l}\text { Materi ajar sesuai dengan tujuan pembelajaran yang memuat materi untuk pengayaan } \\
\text { dan remidi }\end{array}$ & 90 & 16 \\
\hline 6 & Sumber belajar dari buku teks pelajaran, internet, lingkungan alam dan sosial & 84 & 26 \\
\hline 7 & $\begin{array}{l}\text { Memanfaatkan media pembelajaran yang bervariasi (baik sederhana maupun } \\
\text { canggih/multimedia) }\end{array}$ & 74 & 28 \\
\hline 8 & $\begin{array}{l}\text { Media sesuai dengan materi pembelajaran dan menggunakan pendekatan } \\
\text { pembelajaran saintifik }\end{array}$ & 72 \\
\hline 9 & $\begin{array}{l}\text { Kegiatan pendahuluan pembelajaran mencakup kegiatan apersepsi, penyampaian tujuan } \\
\text { pembelajaran, dan kegiatan-kegiatan pembelajaran yang akan dilakukan peserta didik }\end{array}$ & 90 & 10 \\
\hline 10 & $\begin{array}{l}\text { Kegiatan pembelajaran mencakup kegiatan-kegiatan pembelajaran pada tahapan- } \\
\text { tahapan metode saintifik pada inti pembelajaran }\end{array}$ & 80 & 20 \\
\hline 11 & Kegiatan penutup pembelajaran mencakup kegiatan pengayaan dan/atau remedi & 76 & 24 \\
\hline 12 & $\begin{array}{l}\text { Kegiatan pembelajaran secara seimbang mengembangkan sikap, pengetahuan, dan } \\
\text { keterampilan }\end{array}$ & 90 & 10 \\
\hline 13 & $\begin{array}{l}\text { Penilaian sesuai dengan teknik dan bentuk penilaian autentik } \\
14\end{array}$ Penilaian sesuai dengan indikator pencapaian kompetensi & 60 & 40 \\
\hline 15 & Penilaian dilengkapi dengan pedoman penskoran & 62 & 38 \\
\hline
\end{tabular}

Berdasarkan Tabel 3 dapat diketahui bahwa secara umum para guru belum sepenuhnya memahami penyusunan RPP yang sesuai dengan Kurikulum 2013. Penyusunan yang belum dipahami tersebut diantaranya: 1) bahwa sumber belajar dapat dari buku teks pelajaran, internet, lingkungan alam dan sosial, 2) bahwa media pembelajaran dapat bervariasi (baik sederhana maupun canggih/multimedia), 3) bahwa media harus sesuai dengan materi pembelajaran dan menggunakan pendekatan pembelajaran saintifik. 4) bahwa kegiatan pembelajaran mencakup kegiatan-kegiatan pembelajaran pada tahapan-tahapan metode saintifik pada inti pembelajaran, 5) bahwa kegiatan penutup pembelajaran mencakup kegiatan pengayaan dan/atau remidi, 6) bahwa penilaian harus sesuai dengan teknik dan bentuk penilaian autentik, 7) bahwa poenilaian harus sesuai dengan indikator pencapaian kompetensi, 8) bahwa penilaian harus dilengkapi dengan pedoman penskoran. Kenyataan tersebut dapat dimaklumi karena para guru sebagian besar belum memahami prinsip-prinsip pembelajaran dan penilaian yang sesuai dengan Kurikulum 2013. Berdasarkan wawancara yang telah dilakukan, selama ini para guru dalam menyusun RPP lebih sering mengcopy saja contoh-contoh RPP yang ada dan kurang berusaha menyesuaikannya dengan situasi dan kondisi sekolah masing-masing. Oleh karenanya mudah ditebak apa yang terjadi jika mereka sekarang dituntut harus menyesuaikan RPP yang disusun sesuai dengan prinsip-prinsip pembelajaran dan prinsip-prinsip penilain Kurikulum 2013, tentu mereka menjadi kesulitan.

\section{Pandangan Guru Terhadap Kegiatan Pembelajaran}

Setelah dilakukan pemilahan dan pengelompokan data dari angket, dapat disajikan pandangan guru terhadap kegiatan pembelajaran seperti Tabel 4 sebagai berikut: 
Tabel 4. Pandangan Guru Terhadap Kegiatan Pembelajaran

\begin{tabular}{|c|c|c|c|}
\hline \multirow{2}{*}{ No } & \multirow{2}{*}{ Komponen Kurikulum 2013} & \multicolumn{2}{|c|}{ Pelaksanaan (\%) } \\
\hline & & Sudah & Belum \\
\hline & Kegiatan Pendahuluan & & \\
\hline 1 & $\begin{array}{l}\text { Mengaitkan materi pembelajaran sekarang dengan pengalaman peserta didik atau } \\
\text { pembelajaran sebelumnya. }\end{array}$ & 90 & 10 \\
\hline 2 & Mengajukan pertanyaan menantang. & 92 & 8 \\
\hline 3 & Menyampaikan manfaat materi pembelajaran. & 92 & 8 \\
\hline 4 & Mendemonstrasikan sesuatu yang terkait dengan tema. & 72 & 28 \\
\hline 5 & Mengecek perilaku awal (entry behaviour) & 60 & 40 \\
\hline 6 & $\begin{array}{l}\text { Menyampaikan kemampuan yang akan dicapai peserta didik (interaksi KI } 3 \text { dan } \mathrm{KI} 4 \\
\text { yang berimplikasi pada pengembangan } \mathrm{KI} 1 \text { dan } \mathrm{KI} \text { 2). }\end{array}$ & 48 & 82 \\
\hline 7 & Menyampaikan rencana kegiatan pembelajaran & 76 & 24 \\
\hline & Kegiatan Inti & & \\
\hline 1 & Menyesuaikan materi dengan tujuan pembelajaran. & 94 & 6 \\
\hline 2 & $\begin{array}{l}\text { Mengkaitkan materi dengan pengetahuan lain yang relevan, perkembangan Iptek, dan } \\
\text { kehidupan nyata. }\end{array}$ & 90 & 10 \\
\hline 3 & Mengelola pembahasan materi pembelajaran dan pengelaman belajar dengan tepat. & 90 & 10 \\
\hline 4 & Menyajkan materi secara sistematis (mudah ke sulit, dari konkrit ke abstrak) & 84 & 16 \\
\hline 5 & Kegiatan pembelajaran sesuai dengan kompetensi yang akan dicapai. & 90 & 10 \\
\hline 6 & Kegiatan pembelajaran memuat komponen pendahuluan, inti, dan penutup. & 86 & 14 \\
\hline 7 & Kegiatan pembelajaran runtut. & 80 & 20 \\
\hline 8 & Disiplin dan suasana kelas terkelola dengan baik. & 84 & 16 \\
\hline 9 & Pembelajaran kontekstual.dan saintifik & 54 & 46 \\
\hline 10 & Kegiatan pembelajaran mengembangkan sikap spiritual dan sikap sosial peserta didik & 74 & 26 \\
\hline 11 & Pembelajaran dilaksanakan sesuai dengan alokasi waktu yang direncanakan. & 76 & 24 \\
\hline 12 & $\begin{array}{l}\text { Memfasilitasi peserta didik untuk mengamati untuk menemukan masalah yang ingin } \\
\text { diketahui. }\end{array}$ & 86 & 14 \\
\hline 13 & Memancing/memfasilitasi peserta didik untuk merumuskan pertanyaan. & 84 & 16 \\
\hline 14 & $\begin{array}{l}\text { Memfasilitasi peserta didik untuk mengumpulkan informasi/data yang relevan dengan } \\
\text { pertanyaan yang telah dirumuskan }\end{array}$ & 86 & 14 \\
\hline 15 & $\begin{array}{l}\text { Memfasilitasi peserta didik untuk mengolah/menganalisis informasi untuk membuat } \\
\text { kesimpulan. }\end{array}$ & 62 & 38 \\
\hline 16 & Memfasilitasi peserta didik mengomunikasikan pengetahuan yang diperolehnya & 74 & 26 \\
\hline 17 & Menunjukkan keterampilan dalam penggunaan sumber belajar pembelajaran. & 76 & 24 \\
\hline 18 & Menunjukkan keterampilan dalam penggunaan media pembelajaran yang bervariasi. & 64 & 36 \\
\hline 19 & Menghasilkan pesan yang menarik melalui penggunaan media pembelajaran. & 54 & 46 \\
\hline 20 & Melibatkan peserta didik dalam pemanfaatan sumber belajar pembelajaran. & 70 & 30 \\
\hline 21 & Melibatkan peserta didik dalam pemanfaatan media pembelajaran. & 72 & 28 \\
\hline 22 & $\begin{array}{l}\text { Menumbuhkan partisipasi aktif peserta didik (mental, fisik, dan sosial) melalui interaksi } \\
\text { guru, peserta didik, sumber belajar. }\end{array}$ & 76 & 24 \\
\hline 23 & Merespon positif partisipasi peserta didik. & 78 & 22 \\
\hline 24 & Menunjukkan sikap terbuka terhadap respons peserta didik. & 70 & 30 \\
\hline 25 & Menunjukkan hubungan antar pribadi yang kondusif. & 74 & 26 \\
\hline 26 & Menumbuhkan keceriaan atau antusiasme peserta didik dalam belajar. & 72 & 28 \\
\hline 27 & Menggunakan bahasa lisan secara jelas dan lancar. & 74 & 26 \\
\hline 28 & Menggunakan bahasa tulis yang baik dan benar. & 76 & 24 \\
\hline & Kegiatan Penutup & & \\
\hline 1 & Melakukan refleksi dan/atau membuat rangkuman dengan melibatkan peserta didik. & 72 & 28 \\
\hline 2 & Memberikan tes lisan atau tulisan. & 70 & 30 \\
\hline 3 & Mengumpulkan hasil kerja sebagai bahan portofolio. & 60 & 40 \\
\hline 4 & $\begin{array}{l}\text { Memberi tindak lanjut dengan memberikan arahan kegiatan berikutnya dan tugas } \\
\text { pengayaan dan/atau remidi. }\end{array}$ & 72 & 28 \\
\hline
\end{tabular}


Berdasarkan Tabel 4 dapat diketahui bahwa secara umum para guru belum sepenuhnya memahami kegiatan pembelajaran yang sesuai dengan Kurikulum 2013. Kegiatan pembelajaran yang belum dipahami tersebut terutama adalah: 1) bahwa guru harus menyampaikan kemampuan yang akan dicapai peserta didik (interaksi KI 3 dan KI 4 yang berimplikasi pada pengembangan KI 1 dan KI 2). 2) bahwa pembelajaran harus kontekstual dan saintifik, 3) bahwa guru harus memfasilitasi peserta didik untuk mengolah/menganalisis informasi untuk membuat kesimpulan, 4) bahwa guru harus menunjukkan keterampilan dalam penggunaan media pembelajaran yang bervariasi, 5) bahwa Media harus menghasilkan pesan yang menarik melalui penggunaan media pembelajaran, dan kemampuan guru lainnya yang bersesuaian dengan standar proses. Hal tersebut menggambarkan bahwa para guru sebagian besar belum memahami prinsipprinsip pembelajaran yang sesuai dengan Kurikulum 2013. Berdasarkan wawancara yang telah dilakukan, selama ini para guru dalam melaksanakan pembelajaran masih banyak yang bersifat konvensional dengan guru banyak mendominasi pembelajaran.

\section{Pandangan Guru Terhadap Kegiatan Penilaian}

Setelah dilakukan pemilahan dan pengelompokan data dari angket, dapat disajikan pandangan guru terhadap kegiatan pembelajaran seperti Tabel 5 sebagai berikut:

Tabel 5. Pandangan Guru Terhadap Kegiatan Penilaian

\begin{tabular}{|c|l|c|c|}
\hline \multirow{2}{*}{ No } & \multicolumn{1}{|c|}{ Komponen Kurikulum 2013 } & \multicolumn{2}{c|}{ Pelaksanaan (\%) } \\
\cline { 3 - 4 } & & \multicolumn{1}{|c|}{ Sudah } & Belum \\
\hline 1 & $\begin{array}{l}\text { Melaksanakan penilaian sikap selama proses pembelajaran dengan teknik observasi dan } \\
\text { jurnal. }\end{array}$ & 70 & 30 \\
\hline 2 & Mengembangkan instrumen penilaian sikap sesuai dengan kaidah & 60 & 40 \\
\hline 3 & Mengembangkan rubrik penilaian sikap dari instrumen yang dikembangkan & 54 & 40 \\
\hline 4 & Mendokumentasi hasil penilaian sikap. & 60 & 40 \\
\hline 5 & Melaksanakan penilaian pengetahuan dengan tes lisan, tes tulis, dan penugasan & 70 & 30 \\
\hline 6 & Mengembangkan instrumen penilaian pengetahuan sesuai dengan kaidah & 60 & 40 \\
\hline 7 & $\begin{array}{l}\text { Mengembangkan rubrik/pedoman penskoran penilaian pengetahuan dari instrumen yang } \\
\text { dikembangkan }\end{array}$ & 64 & 36 \\
\hline 8 & Mendokumentasi hasil penilaian pengetahuan. & 70 & 30 \\
\hline 9 & Melaksanakan penilaian keterampilan dengan praktik, projek, dan portofolio & 64 & 36 \\
\hline 10 & Mengembangkan instrumen penilaian keterampilan sesuai dengan kaidah & 54 & 40 \\
\hline 11 & Mengembangkan rubrik penilaian keterampilan dari instrumen yang dikembangkan & 46 & 54 \\
\hline 12 & Mendokumentasi hasil penilaian keterampilan. & 70 & 30 \\
\hline
\end{tabular}

Berdasarkan Tabel 5 dapat diketahui bahwa secara umum para guru belum sepenuhnya memahami kegiatan penilaian yang sesuai dengan Kurikulum 2013. Kegiatan penilaian yang belum dipahami tersebut terutama adalah: 1) bagaimana mengembangkan instrumen penilaian sesuai dengan kaidah, dan 2) bagaimana mengembangkan rubrik penilaian dari instrumen yang dikembangkan tersebut. Hal ini menggambarkan bahwa para guru sebagian besar belum memahami prinsip- prinsip penilaian yang sesuai dengan standar penilaian. Berdasarkan wawancara yang telah dilakukan, selama ini para guru dalam mengembangkan penilaian masih banyak yang mengadopsi penilaian yang terdapat pada buku-buku tanpa berusaha menyesuaikannya dengan karakteristik siswa di sekolahnya. Seharusnya para guru dapat mengembangkan instrumen penilaian dan rubriknya sesuai dengan karakteristik dari siswa dan karakteristik sekolahnya masing-masing. 
ISSN: 2087-9946

\section{Harapan dan tantangan dalam pelaksanaan Kurikulum 2013}

Kurikulum 2013 mengandung pemikiranpemikiran untuk melakukan terobosan agar praktik pembelajaran di sekolah lebih baik yaitu mengembangkan potensi siswa secara maksimal dengan pembelajaran yang berpusat pada siswa. Usaha pemerintah dengan segenap daya dan dana tersebut perlu mendapatkan apresiasi semua pihak yang berkepentingan.

Menurut PP No. 54 Th $2013^{[12]}$, Standar Kompetensi Lulusan (SKL) adalah kriteria mengenai kualifikasi kemampuan lulusan yang mencakup sikap, pengetahuan, dan keterampilan. SKL digunakan sebagai acuan utama pengembangan standar isi, standar proses, standar penilaian pendidikan, standar pendidik dan tenaga kependidikan, standar sarana dan prasarana, standar pengelolaan, dan standar pembiayaan. SKL tersebut diturunkan dari kebutuhan (bukan dari standar isi). SKL untuk jentang SMK/MAK adalah sebagai berikut:

1. Memiliki perilaku yang mencerminkan sikap orang beriman, berakhlak mulia, berilmu, percaya diri, dan bertanggung jawab dalam berinteraksi secara efektif dengan lingkungan sosial dan alam serta dalam menempatkan diri sebagai cerminan bangsa dalam pergaulan dunia (dimensi sikap).

2. Memiliki pengetahuan faktual, konsep-tual, prosedural, dan metakognitif dalam ilmu pengetahuan, teknologi, seni, dan budaya dengan wawasan kemanusiaan, kebangsaan, kenegaraan, dan peradaban terkait penyebab serta dampak fenomena dan kejadian (dimensi pengetahuan)

3. Memiliki kemampuan pikir dan tindak yang efektif dan kreatif dalam ranah abstrak dan konkret sebagai pengembangan dari yang dipelajari di sekolah secara mandiri (dimensi keterampilan)

Menurut Permendikbud No. 70 th 2013 tentang Kerangka Dasar dan Struktur Kurikulum SMK/MAK ${ }^{[13]}$, Kurikulum 2013 dikembangkan dengan penyempurnaan pola ppikir sebagai berikut:
1. pola pembelajaran yang berpusat pada guru menjadi pembelajaran berpusat pada peserta didik. Peserta didik harus memiliki pilihan-pilihan terhadap materi yang dipelajari untuk memiliki kompetensi yang sama;

2. pola pembelajaran satu arah (interaksi guru-peserta didik) menjadi pembelajaran interaktif (interaktif guru - peserta didik masyarakat - lingkungan alam, sumber/media lainnya);

3. pola pembelajaran terisolasi menjadi pembelajaran secara jejaring (peserta didik dapat menimba ilmu dari siapa saja dan dari mana saja yang dapat dihubungi serta diperoleh melalui internet);

4. pola pembelajaran pasif menjadi pembelajaran aktif-mencari (pembelajaran siswa aktif mencari semakin diperkuat dengan model pembelajaran pendekatan sains);

5. pola belajar sendiri menjadi belajar kelompok (berbasis tim);

6. pola pembelajaran alat tunggal menjadi pembelajaran berbasis alat multimedia;

7. pola pembelajaran berbasis massal menjadi kebutuhan pelanggan (users) dengan memperkuat pengembangan potensi khusus yang dimiliki setiap peserta didik;

8. pola pembelajaran ilmu pengetahuan tunggal (monodiscipline) menjadi pembelajaran ilmu pengetahuan jamak (multidisciplines); dan

9. pola pembelajaran pasif menjadi pembelajaran kritis.

Terkait dengan pola pikir di atas, maka guru harus berusaha memperbaiki pola pikir lama yang tidak sesuai dengan Kurikulum 2013. Bagaimanapun guru adalah pihak yang paling menentukan dalam keberhasilan pelaksanaan Kurikulum 2013.

Menurut Permendikbud No, 65 th $2013^{[14]}$ tentang Standar Proses, proses pembelajaran pada satuan pendidikan diselenggarakan secara interaktif, inspiratif, menyenangkan, menantang, memotivasi peserta didik untuk berpartisipasi aktif, serta memberikan ruang yang cukup bagi prakarsa, kreativitas, dan kemandirian sesuai dengan bakat, minat, dan 


\section{ISSN: 2087-9946}

perkembangan fisik serta psikologis peserta didik. Untuk itu setiap satuan pendidikan melakukan perencanaan pembelajaran, pelaksanaan proses pembelajaran serta penilaian proses pembelajaran untuk meningkatkan efisiensi dan efektivitas ketercapaian kompetensi lulusan. Sesuai dengan Standar Kompetensi Lulusan dan Standar Isi maka prinsip pembelajaran yang digunakan:

1. dari peserta didik diberi tahu menuju peserta didik mencari tahu;

2. dari guru sebagai satu-satunya sumber belajar menjadi belajar berbasis aneka sumber belajar;

3. dari pendekatan tekstual menuju proses sebagai penguatan penggunaan pendekatan ilmiah;

4. dari pembelajaran berbasis konten menuju pembelajaran berbasis kompetensi;

5. dari pembelajaran parsial menuju pembelajaran terpadu;

6. dari pembelajaran yang menekankan jawaban tunggal menuju pembelajaran dengan jawaban yang kebenarannya multi dimensi;

7. dari pembelajaran verbalisme menuju keterampilan aplikatif;

8. peningkatan dan keseimbangan antara keterampilan fisikal (hardskills) dan keterampilan mental (softskills);

9. pembelajaran yang mengutamakan pembudayaan dan pemberdayaan peserta didik sebagai pembelajar sepanjanghayat;

10. pembelajaran yang menerapkan nilai-nilai dengan member keteladanan (ing ngarso sung tulodo), membangun kemauan (ing madyo mangun karso), dan mengembangkan kreativitas peserta didik dalam proses pembelajaran (tut wuri handayani);

11. pembelajaranyang berlangsung di rumah, di sekolah, dan di masyarakat;

12. pembelajaran yang menerapkan prinsip bahwa siapa saja adalah guru, siapa saja adalah siswa, dan di mana saja adalah kelas.

13. Pemanfaatan teknologi informasi dan komunikasi untuk meningkatkan efisiensi dan efektivitas pembelajaran; dan
14. Pengakuan atas perbedaan individual dan latar belakang budaya peserta didik.

Terkait dengan prinsip di atas, dikembangkan standar proses yang mencakup perencanaan proses pembelajaran, pelaksanaan proses pembelajaran, penilaian hasil pembelajaran, dan pengawasan proses pembelajaran.

Menurut Permendikbud No. 66 th $2013^{[15]}$ tentang Standar Penilaian, disebutkan bahwa Standar Penilaian Pendidikan adalah kriteria mengenai mekanisme, prosedur, dan instrumen penilaian hasil belajar dam pembelajaran peserta didik. Penilaian pendidikan sebagai proses pengumpulan dan pengolahan informasi untuk mengukur pencapaian hasil belajar peserta didik mencakup: penilaian otentik, penilaian diri, penilaian berbasis portofolio, ulangan, ulangan harian, ulangan tengah semester, ulangan akhir semester, ujian tingkat kompetensi, ujian mutu tingkat kompetensi, ujian nasional, dan ujian sekolah/ madrasah. Pendekatan penilaian yang digunakan adalah penilaian acuan criteria (PAK). PAK merupakan penilaian pencapaian kompetensi yang didasarkan pada kriteria ketuntasan minimal (KKM). KKM merupakan criteria ketuntasan belajar minimal yang ditentukan oleh satuan pendidikan dengan mempertimbangkan karakteristik Kompetensi Dasar yang akan dicapai, daya dukung, dan karakteristik peserta didik. Beberapa hal penting terkait penilaian dalam Kurikulum 2013 yaitu:

1. Penilaian hasil belajar peserta didik mencakup kompetensi sikap, pengetahuan, dan keterampilan yang dilakukan secara berimbang sehingga dapat digunakan untuk menentukan posisi relatif setiap peserta didik terhadap standar yang telah ditetapkan. Cakupan penilaian merujuk pada ruang lingkup materi, kompetensi mata pelajaran/kompetensi muatan/kompetensi program, dan proses.

2. Pendidik melakukan penilaian kompetensi sikap melalui observasi, penilaian diri, penilaian "teman sejawat"(peer evaluation) oleh peserta didik dan jurnal.

3. Pendidik menilai kompetensi pengetahuan melalui tes tulis, tes lisan, dan penugasan. 
ISSN: 2087-9946

4. Pendidik menilai kompetensi keterampilan melalui penilaian kinerja, yaitu penilaian yang menuntut peserta didik mendemonstrasikan suatu kompetensi tertentu dengan menggunakan tes praktik, projek, dan penilaian portofolio.

5. Instrumen penilaian harus memenuhi persyaratan: 1) substansi yang merepresentasikan kompetensi yang dinilai; 2) konstruksi yang memenuhi persyaratan teknis sesuai dengan bentuk instrumen yang digunakan; dan 3) penggunaan bahasa yang baik dan benar serta komunikatif sesuai dengan tingkat perkembangan peserta didik.

Harapan dari pelaksanaan Kurikulum 2013 adalah bagaimana kurikulum tersebut dapat dilaksanakan sesuai dengan standar yang telah ditetapkan, sedangkan tantangan terbesar dari pelaksanaan Kurikulum 2013 adalah bagaimana para guru menyikapi dan upaya yang dilakukan terkait Kurikulum 2013 tersebut secara tepat. Penulis memandang ada beberapa langkah yang perlu dikembangkan oleh para guru dalam mendukung keberhasilan pelaksanaan Kurikulum 2013 yaitu:

1. Mengembangkan RPP yang dapat memberdayakan potensi siswa dan memfasilitasi siswa untuk membangun keterampilan hidup (Lile Skill),

2. Mengembangkan pembelajaran yang berpusat pada siswa (student centered) yang melatih secara berimbang kompetensi sikap, pengetahuan, keterampilan.

3. Mengembangkan pembelajaran interaktif melibatkan interaksi siswa dengan berbagai sumber belajar;

4. Mengembangkan pembelajaran yang melatih siswa mencari informasi dari berbagai sumber belajar,

5. Mengembangkan pembelajaran yang aktif, inovatif, kreatif, efektif, dan menyenangkan, yang berbasis belajar kelompok,

6. Mengembangkan pembelajaran berjejaring sehingga siswa dapat belajar dari siapa saja dan dari mana saja yang dapat dihubungi serta diperoleh melalui internet,

7. Mengembangkan pembelajaran kontekstual dengan memanfaat alat peraga dan multimedia yang sesuai.
8. Mengembangkan pembelajaran fisika terpadu dan ilmu pengetahuan jamak (multidisciplines),

9. Mengembangkan pembelajaran yang melatih siswa berpikir kritis, analitis, logis, dan kreatif.

10. Mengembangkan lembar kerja siswa (LKS) yang memfasilitasi siswa agar memperoleh ilmu pengetahuan melalui keterampilan proses sains (LKS dibuat sendiri oleh guru dan bukan dari membeli), dan LKS bukan "lembar kumpulan soal",

11. Mengembangkan penilaian yang mencakup sikap, pengetahuan, dan keterampilan yang berupa penilaian autentik dengan teknik yang sesuai (tes, kinerja, portofolio,dll),

12. Mengembangkan kegiatan refleksi siswa untuk menyampaikan dan menjelaskan kesimpulan diskusi kelompoknya, dan mendorong siswa sendiri yang menyampiakan kesimpulan,

\section{SIMPULAN DAN SARAN}

Dari hasil penelitian pelaksanaan Kurikulum 2013 untuk pembelajaran Fisika SMK di kota Surabaya, dapat disimpulkan:

1. Para guru berpandangan belum sepenuhnya memahami prinsip pembelajaran terutama yang terkait dengan: perbedaan pendekatan tekstual dengan pendekatan ilmiah, perbedaan pembelajaran parsial dengan pembelaran terpadu, perbedaan pembelajaran yang menekankan jawaban tunggal dengan pembelajaran yang membutuhkan jawaban multi dimensi, perbedaan pembelajaran verbalisme dengan pembelajaran yang aplikatif, dan pembelajaran yang berprinsip bahwa siapa saja adalah guru, siapa saja adalah siswa, dan di mana saja adalah kelas .

2. Para guru berpandangan belum sepenuhnya memahami prinsip penilaian diantaranya: cara menilai kompetensi sikap, cara menilai keterampilan, dan menyusun instrumen penilaian yang sesuai kaidah.

3. Para guru berpandangan penyusunan RPP masih terkendala terutama pada: berbagai sumber belajar (buku teks, internet, lingkungan alam dan sosial), media 


\section{ISSN: 2087-9946}

pembelajaran yang bervariasi, media yang sesuai dengan materi pembelajaran, pendekatan pembela-jaran saintifik. penilaian autentik, penilaian yang sesuai dengan indikator pencapaian kompetensi, dan pedoman penskoran.

4. Para guru berpandangan masih belum dapat melaksanakan kegiatan pembelajaran yang sesuai dengan standar proses meliputi: belum terbiasa menyampaikan kompetensi yang akan dicapai kepada peserta didik, belum melaksanakan pembelajaran kontekstual dan saintifik, belum memfasilitasi peserta didik mengolah/ menganalisis informasi untuk membuat kesimpulan, belum menggunakan media pembelajaran yang bervariasi, dan media yang digunakan belum menghasilkan pesan yang menarik

5. Para guru berpandangan masih belum dapat melaksanakan penilaian sesuai standar penilaian terutama terhadap: bagaimana cara mengembangkan instrumen penilaian yang sesuai dengan kaidah, dan bagaimana cara mengembangkan rubrik penilaian dari instrumen yang dikembangkan tersebut. .

6. Harapan dari pelaksanaan Kurikulum 2013 adalah kurikulum tersebut dapat dilaksanakan sesuai dengan standar yang telah ditetapkan, sedangkan tantangan terbesar dari pelaksanaan Kurikulum 2013 adalah bagaimana para guru dapat menyikapi dan mengupayakan pelaksanaan secara tepat kurikulum tersebut.

Saran yang dapat dikemukakan terkait pelaksanaan Kurikulum 2013 adalah meningkatkan kegiatan pendampingan Kurikulum 2013 kepada para guru-guru Fisika SMK/MAK dan lebih mengintensifkan peran MGMP dalam membantu meningkatkan kompetensi dari para guru anggotanya.

\section{DAFTAR PUSTAKA}

[1] Marsigit, 2013, Tantangan dan Harapan Kurikulum 2013 Bagi Pendidikan Matematika, Seminar Nasional Matematika dan Pendidikan Universitas PGRI Yogyakarta Yogyakarta, 18 Juni 2013

[2] Trilling, B. dan Hood, P. 1999. Learning,
Technology, and Education Reform in the Knowledge Age or "We're Wired, Webbed, and Windowed, Now What"? Educational Technology may-June 1999.

[3] Ruiz M.A., Primo, 2009, Towards a Framework for Assessing 21st Century Science Skills, Commissioned paper for The National Academies, University of Colorado Denver,February, 2009

[4] De Vito, Alfred. 1989. Creative Wellsprings for Science Teaching. West Lafayette, Indiana: Creative Venture.

[5] Wyatt, A.T., Critical Thinking. Tersedia pada

http://eduscapes.com/tap/topic69.htm.

Diakses pada 14 des 2013

[6] Gie, T.L.. 2003. Teknik Berpikir Kreatif. Yogyakarta: Sabda Persada.

[7] Kemdikbud, 2012, Pengamtar Uji Publik Pengembangan Kurikulum 2013. Kementrian Pendidikan dan Kebudayaan, Desember 2012.

[8] Kemdikbud, 2013, Materi Pelatihan Guru, Pelaksanaan Kurikulum 2013 SMP/MTs Ilmu Pengetahuan Alam, Badan Pengembangan Sumber Daya Manusia Pendidikan dan Kebudayaan dan Penjaminan Mutu Pendidikan Kementerian Pendidikan dan Kebudayaan.

[9] Sukmadinata, 2012, Metode Penelitian Pendidikan, Remaja Rosdakarya, Bandung.

[10] Neuman, W. Lawrence. 2006. Social Research Methods: Qualitative and Quantitative Research. USA: University of Wisconsin.

[11] Suharsimi, 2002, Prosedur Penelitian Suatu Pendekatan Praktek, Edisi V, Jakarta: Rineka Cipta.

[12] Permendikbud No. 54 Tahun 2013 tentang SKL;

[13] Permendikbud No. 70 Tahun 2013 tentang Kerangka Dasar dan Struktur Kurikulum SMK-MAK.

[14] Permendikbud No. 65 Tahun 2013 tentang Standar Proses;

[15] Permendikbud No. 66 Tahun 2013 tentang Standar Penilaian; 